\title{
An alternative method for inactivating heteroagglutinins in human sera applicable to rubella haemagglutination inhibition testing at low dilutions
}

\author{
P. P. MORTIMER
}

From the Virus Reference Laboratory, Central Public Health Laboratory, Colindale Avenue, London NW9 $5 H T$

SYNOPSIS Serum agglutinins of chick and pigeon cells are predominantly immunoglobulin $\mathbf{M}$ and can be inactivated by 2 mercaptoethanol. 2 Mercaptoethanol is more effective than strong suspensions of red cells in removing the agglutinins of indicator cells from sera being prepared for HAI tests. In rubella HAI tests from a dilution of 1 in 10 dilute 2 mercaptoethanol offer a convenient method of removing agglutinins, and, at a higher concentration, allow dilutions of sera from 1 in 2.5 to be tested without significant interference by heteroagglutinins. HAI titres are comparable when red cell absorbed and 2 mercaptoethanol treated sera are tested in parallel.

Human sera contain agglutinins to the erythrocytes of a wide range of animals and birds. In haemagglutination inhibition (HAI) tests these 'hetero'-agglutinins produce a pattern of agglutination of indicator red cells similar to specific haemagglutination and often mask inhibition by low titres of antibody. Although heteroagglutinins may be removed from sera by treatment with strong suspensions of cells absorption is slow and incomplete. It has also been suggested that the incubation of red cells with sera releases significant amounts of cell membrane lipoprotein which may act as a non-specific inhibitor (Saeed and Murray, 1975).

In rubella HAI tests pigeon and day-old chick cells are most commonly used as indicator cells, though agglutinin to the red cells of both these species is present in human sera. Cell agglutinin can be partially removed from sera by absorption, but at dilutions of sera below 1 in 20 residual agglutinins, particularly to pigeon cells, often make the detection of rubella haemagglutination inhibition impossible. At dilutions below 1 in 10 non-specific agglutination is also caused by divalent cations added to precipitate nonantibody inhibitors.

Biano et al (1974) used strong cell suspensions to absorb heteroagglutinins, and sodium carbonate to precipitate excess manganese ions, and were thus able to read rubella HAI tests from a dilution of 1 in 4 . In this paper alternative methods

Received for publication 25 September 1975 for removing agglutinins by treating sera with 2 mercaptoethanol (2 ME) are described, and applied to rubella HAI testing from serum dilutions of 1 in 10 and 1 in $2 \cdot 5$.

\section{Material and Methods}

SERA

Sera were collected from women attending antenatal clinics and were stored at $-20^{\circ} \mathrm{C}$ until used.

SERUM TREATMENT

Non-antibody inhibitors of rubella haemagglutination were precipitated by adding to sera the same volume of a freshly prepared mixture of equal proportions of molar manganese chloride and heparin. Heparin was diluted in dextrose gelatin veronal buffer (DGV) from a stock solution in distilled water of 25000 units per $\mathrm{ml}$ for use at a strength of 5000 units per ml. Agglutinins were removed either by absorbing sera with concentrated suspensions of red cells for $2 \mathrm{~h}$ at $4^{\circ} \mathrm{C}$ or by adding diluted $2 \mathrm{ME}$ and incubating sera for $30 \mathrm{~min}$ in a $37^{\circ} \mathrm{C}$ waterbath. Dilutions of $2 \mathrm{ME}$ were prepared in DGV from a stock molar solution. The following methods of serum preparation were used:

Method A (chick cells)

Final serum dilution 1 in 5

$\operatorname{Mix}\left\{\begin{array}{l}0.10 \mathrm{ml} \text { serum } \\ 0.10 \mathrm{ml} \text { heparin } / \mathrm{MnC1}_{2} \\ 0.20 \mathrm{ml} \mathrm{DGV}\end{array}\right\} \begin{aligned} & \text { Incubate at } 4^{\circ} \mathrm{C} \\ & \text { for } 20 \mathrm{~min} .\end{aligned}$ 
Centrifuge at $2000 \mathrm{rev} / \mathrm{min}$ for $20 \mathrm{~min}$ and remove $0 \cdot 20 \mathrm{ml}$ of supernatant.

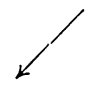

Add 0.05 ml 0.02 molar $2 \mathrm{ME}$, incubate at $37^{\circ} \mathrm{C}$

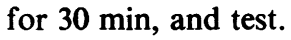

Add $0.05 \mathrm{ml} \mathrm{20 \%}$ chick cells and incubate at $4^{\circ} \mathrm{C}$ for $2 \mathrm{~h}$. Centrifuge at 900 $\mathrm{rev} / \mathrm{min}$ for $10 \mathrm{~min}$ and test supernatant.

Method B (pigeon cills)

Final serum dilution 1 in 5

$\operatorname{Mix}\left\{\begin{array}{l}0.10 \mathrm{ml} \text { serum } \\ 0.10 \mathrm{ml} \text { heparin/ } / \mathrm{MnC1}_{2} \\ 0.20 \mathrm{ml} \mathrm{DGV}\end{array}\right\} \begin{aligned} & \text { Incubate at } 4^{\circ} \mathrm{C} \\ & \text { for } 20 \mathrm{~min} .\end{aligned}$ Centrifuge at $2000 \mathrm{rev} / \mathrm{min}$ for $20 \mathrm{~min}$ and remove $0.20 \mathrm{ml}$ of supernatant.

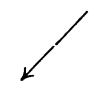

Add $0.05 \mathrm{ml} \mathrm{0.2}$ molar for $2 \mathrm{ME}$, incubate at $37^{\circ} \mathrm{C} 30 \mathrm{~min}$, and test.
Add $0.075 \mathrm{ml} 33 \%$ pigeon cells and incubate at $4^{\circ} \mathrm{C}$ for $2 \mathrm{~h}$. Centrifuge at 900 $\mathrm{rev} / \mathrm{min}$ for $10 \mathrm{~min}$ and test supernatant.

Method C (chick cells)

Final serum dilution 1 in $2 \cdot 5$

$\operatorname{Mix}\left\{\begin{array}{l}0.2 \mathrm{ml} \text { serum } \\ 0.2 \mathrm{ml} \text { heparin/ } \mathrm{MnCl}_{2}\end{array}\right\} \begin{aligned} & \text { Incubate at } 4^{\circ} \mathrm{C} \\ & \text { for } 20 \mathrm{~min} .\end{aligned}$ Centrifuge at $2000 \mathrm{rev} / \mathrm{min}$ for $20 \mathrm{~min}$ and remove $0.20 \mathrm{ml}$ of supernatant.

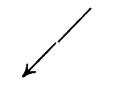

Add 0.025 ml 0.2 molar $2 \mathrm{ME}$ and incubate at $37^{\circ} \mathrm{C}$ for $30 \mathrm{~min}$. Add $0.025 \mathrm{ml}$ 1.0 molar $\mathrm{Na}_{2} \mathrm{CO}_{3}$ and shake vigorously for $1 \mathrm{~min}$. Centrifuge at $2000 \mathrm{rev} / \mathrm{min}$ for $20 \mathrm{~min}$ and test supernatant.

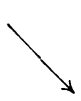

Add $0.05 \mathrm{ml} 50 \%$

chick cells and incubate at $4^{\circ} \mathrm{C}$ for $2 \mathrm{~h}$. Centrifuge at $900 \mathrm{rev} /$ $\mathrm{min}$ for $10 \mathrm{~min}$, remove supernatant, and add $0.025 \mathrm{ml} 1.0$ molar $\mathrm{Na}_{2} \mathrm{CO}_{3}$. Shake vigorously for 1 min and centrifuge at $2000 \mathrm{rev} / \mathrm{min}$ for 10 min. Test supernatant.

Centrifugation procedures were carried out at $4^{\circ} \mathrm{C}$ on the multiple swing-out head of an MSE mistral $4 \mathrm{~L}$ centrifuge.

SERUM FRACTIONATION

Density gradients of $15.0 \%$ to $37.5 \%$ sucrose were prepared in $5 \mathrm{ml}$ centrifuge tubes, and $0.4 \mathrm{ml}$ volumes of serum diluted with $0.2 \mathrm{ml} \mathrm{DGV}$ were layered onto $\underline{\text { 을 }}$ them. The tubes were centrifuged at $4^{\circ} \mathrm{C}$ on a $50 \mathrm{~L}$ swing-out rotor at $35000 \mathrm{rev} / \mathrm{min}(100000 \mathrm{~g})$ for $17 \mathrm{~h} \stackrel{\vec{\rho}}{\stackrel{\rho}{\circ}}$ in a Beckman L3-50 centrifuge. Twelve fractions were collected and tested for chick and pigeon cell $\frac{\bar{\sigma}}{\bar{N}}$ agglutinins with and without treatment with molar $\frac{\bar{s}}{\bar{D}}$ $2 \mathrm{ME}$, and for immunoglobulin class by double $\stackrel{\varnothing}{\varrho}$ diffusion in $1 \%$ agarose against antihuman immuno- $\frac{\sim}{\omega}$ globulin $\mathbf{M}(\mathrm{IgM})$ and immunoglobulin $\mathbf{G}(\mathrm{IgG})$ sera (Wellcome Laboratories).

HAEMAGGLUTINATION INHIBITION AND CELL
AGGLUTINATION TESTS A conventional three-volume test in microtitre plates was used. The diluent was DGV, pH 7.2. Red i cells of day-old chicks and pigeons were prepared as $\nexists$ $0.25 \%$ and $0.20 \%$ suspensions respectively. Rubella $\vec{v}$ antigen was kindly supplied by the Standards음 Laboratory, Central Public Health Laboratories, $-\overrightarrow{7}$ Colindale. It was used diluted in DGV with $0.2 \%$ bovine plasma albumin (BPA) to a dose of 6 haemagglutination (HA) units. In cell agglutination tests $\overrightarrow{0}$ DGV with $0.2 \%$ BPA was substituted for antigen.के Serum dilutions were incubated with antigen for $1 \mathrm{~h}$. at room temperature and, after the addition of cells, 요 for $2 \mathrm{~h}$ at $4^{\circ} \mathrm{C}$. Plates were left on the bench for 15 min and read. Titres of HAI antibody and of red cell heteroagglutinin were taken as the highest dilution at: which agglutination was completely absent. In $\underset{\Rightarrow}{\Rightarrow}$ serum controls degrees of agglutination were을 recorded as 'Ag' (agglutination which would inter- $\frac{3}{5}$ fere with test reading), 'sl' for slight, and 'tr' for trace agglutination.

\section{Results}

EFFECT OF 2 ME ON SERUM AGGLUTINATION TITRES TO CHICK AND PIGEON CELLS

Twenty-four unselected sera from adult patients were $>$ tested untreated, and treated with $1 / 10$ volume of $0 \cdot 1$ 을. molar, 0.2 molar, and 1.0 molar $2 \mathrm{ME}$ (table I). N Agglutinin of chick cells was present at relatively low titres, and could be lowered to below the serum $\tilde{S}$ dilutions used in rubella HAI tests by $1 / 10$ volume of 0.1 molar $2 \mathrm{ME}$. Pigeon cell agglutinin titres were higher, but fell below the working serum dilutionso after treatment with $1 / 10$ volume of 1.0 molar 2 ME. However they were not adequately removed by $\stackrel{\circ}{+}$ weaker solutions of $2 \mathrm{ME}$.

\section{SEPARATION OF HETEROAGGLUTININS IN} SUCROSE DENSITY GRADIENTS

Three sera with high agglutinin titres to both chicko and pigeon cells were fractionated in sucrose density gradients, and fractions were tested with and withouto 


\begin{tabular}{|c|c|c|c|c|c|c|c|c|}
\hline \multirow[t]{2}{*}{ Serum } & \multicolumn{4}{|c|}{ Chick Cell Agglutinin (reciprocal titre) } & \multicolumn{4}{|c|}{ Pigeon Cell Agglutinin (reciprocal titre) } \\
\hline & Untreated & $0 \cdot 1 M 2 M E$ & $0 \cdot 2 M 2 M E$ & $1 \cdot O M 2 M E$ & Untreated & $O \cdot I M 2 M E$ & $0 \cdot 2 M 2 M E$ & $1 \cdot O M 2 M E$ \\
\hline 1 & 16 & 8 & 4 & 2 & 64 & 128 & 32 & 8 \\
\hline 2 & 8 & 4 & 2 & 2 & 256 & 128 & 8 & 4 \\
\hline 3 & 4 & 4 & $\mathbf{N}$ & 2 & 32 & 16 & 2 & 4 \\
\hline 4 & 4 & 4 & $\mathbf{N}$ & $\mathbf{N}$ & 32 & 16 & 4 & 4 \\
\hline 5 & 4 & 2 & $\mathbf{N}$ & $\mathbf{N}$ & 256 & 256 & 8 & 4 \\
\hline 6 & 4 & 2 & $\mathbf{N}$ & $\mathbf{N}$ & 64 & 32 & 2 & 2 \\
\hline 7 & 4 & 2 & 2 & 2 & 256 & 64 & 4 & 2 \\
\hline 8 & 8 & 8 & 2 & $\mathbf{N}$ & 32 & 16 & 4 & 4 \\
\hline 9 & 4 & 2 & $\mathbf{N}$ & $\mathbf{N}$ & 128 & 64 & 16 & 8 \\
\hline 10 & 2 & 2 & 2 & $\mathbf{N}$ & 256 & 128 & 8 & 4 \\
\hline 11 & 4 & 2 & $\mathbf{N}$ & $\mathbf{N}$ & 256 & 128 & 8 & 2 \\
\hline 12 & 4 & $\mathbf{N}$ & $\mathbf{N}$ & $\mathbf{N}$ & 64 & 16 & 4 & 4 \\
\hline 13 & 2 & $\mathbf{N}$ & $\mathbf{N}$ & $\mathbf{N}$ & 128 & 64 & 32 & 16 \\
\hline 14 & 32 & 4 & 2 & $\mathbf{N}$ & 128 & 32 & 16 & 8 \\
\hline 15 & 8 & 4 & $\mathbf{N}$ & 2 & 256 & 64 & 32 & 16 \\
\hline 16 & 4 & 2 & 2 & $\mathbf{N}$ & 256 & 16 & 2 & 4 \\
\hline 17 & 8 & 4 & $\mathbf{N}$ & $\mathbf{N}$ & 16 & 8 & 2 & 2 \\
\hline 18 & 32 & 8 & 2 & $\mathbf{N}$ & 256 & 256 & 16 & 8 \\
\hline 19 & 2 & 2 & $\mathbf{N}$ & $\mathbf{N}$ & 32 & 16 & 4 & 2 \\
\hline 20 & 4 & 4 & 2 & $\mathbf{N}$ & 16 & 16 & 8 & 2 \\
\hline 21 & 2 & $\mathbf{N}$ & $\mathbf{N}$ & $\mathbf{N}$ & 128 & 32 & 16 & 16 \\
\hline 22 & 4 & 2 & $\mathbf{N}$ & $\mathbf{N}$ & 16 & 16 & 4 & 2 \\
\hline 23 & 4 & 2 & 2 & $\mathbf{N}$ & 128 & 32 & 8 & 8 \\
\hline 24 & 16 & 2 & 2 & $\mathbf{N}$ & 256 & 64 & 16 & 4 \\
\hline \multirow{2}{*}{$\begin{array}{l}\text { Geometric } \\
\text { mean }\end{array}$} & & & & & & & & \\
\hline & $5 \cdot 3$ & 2.7 & 1.4 & 1.2 & 93.0 & $42 \cdot 0$ & 7.0 & 4.5 \\
\hline
\end{tabular}

Table I Effect of varying concentrations of $2 \mathrm{ME}$ on serum agglutinin of chick and pigeon erythrocytes $\mathbf{N}=$ neat

treatment with $1 / 10$ volume of 1.0 molar $2 \mathrm{ME}$ (figure). Double diffusion tests of fractions with anti IgM and anti IgG sera showed that the peak agglutinin activity in fraction 4 corresponded to the highest concentration of IgM, and that there was no separate peak of agglutinin between fractions 6 and 9 where IgG was concentrated. Almost all chick cell agglutinin and most pigeon cell agglutinin in the first six fractions were inactivated by treatment with molar 2 ME.

COMPARISON OF RUBELLA HAI TITRES OF 23 POSITIVE SERA TREATED WITH 2 ME AND ABSORBED WITH RED CELL SUSPENSIONS Twenty-three sera from antenatal patients and a high titred control serum were titrated against $6 \mathrm{HA}$ units

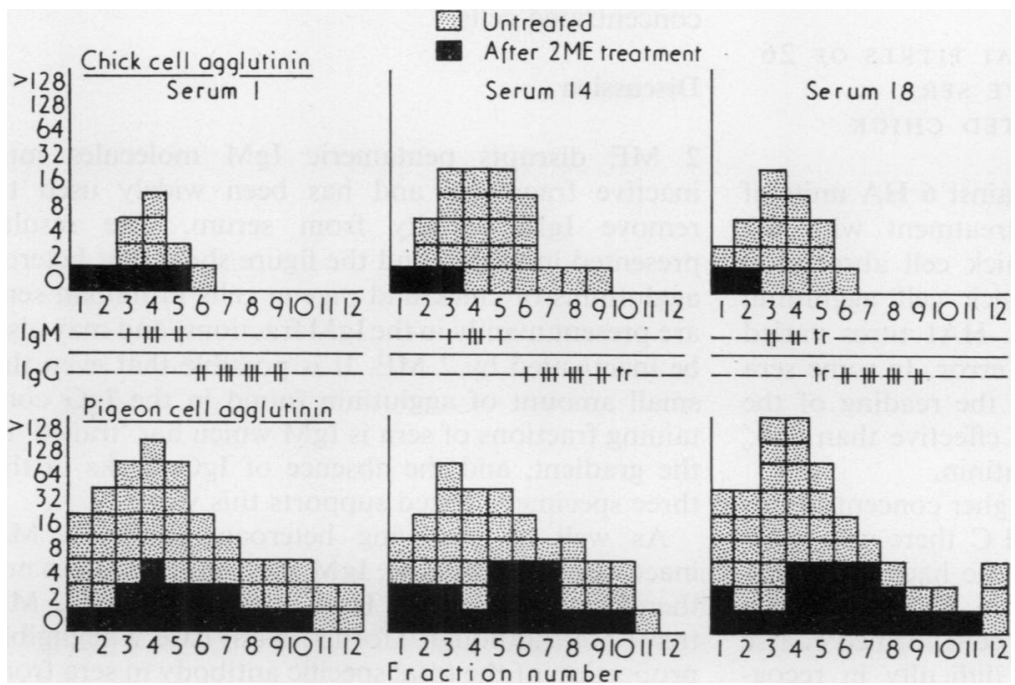

Figure Reciprocal of red cell agglutinin titres of fractions of three sera taken from sucrose density gradients. 


\begin{tabular}{|c|c|c|c|c|c|c|c|c|c|c|c|c|}
\hline \multirow[t]{3}{*}{ Serum } & \multicolumn{6}{|c|}{ Method A: Chick Indicator Cells } & \multicolumn{6}{|c|}{ Method B: Pigeon Indicator Cells } \\
\hline & \multicolumn{3}{|c|}{$\begin{array}{l}2 \text { ME Treated Serum } \\
\text { Control }\end{array}$} & \multicolumn{3}{|c|}{$\begin{array}{l}\text { Chick Cell Absorbed Serum } \\
\text { Control }\end{array}$} & \multicolumn{3}{|c|}{$\begin{array}{l}2 M E \text { Treated Serum } \\
\text { Control }\end{array}$} & \multicolumn{3}{|c|}{$\begin{array}{l}\text { Pigeon Cell Absorbed Serum } \\
\text { Control }\end{array}$} \\
\hline & $\begin{array}{l}\text { HAI } \\
\text { Reciprocal } \\
\text { Titre }\end{array}$ & $1 / 10$ & $1 / 20$ & $\begin{array}{l}\text { HAI } \\
\text { Reciprocal } \\
\text { Titre }\end{array}$ & $1 / 10$ & $1 / 20$ & $\begin{array}{l}\text { HAI } \\
\text { Reciprocal } \\
\text { Titre }\end{array}$ & $1 / 10$ & $1 / 20$ & $\begin{array}{l}\text { HAI } \\
\text { Reciprocal } \\
\text { Titre }\end{array}$ & $1 / 10$ & $1 / 20$ \\
\hline 25 & 80 & - & - & 40 & - & - & 80 & sl & - & 80 & sl & - \\
\hline 26 & 160 & $\operatorname{tr}$ & - & 160 & sl & - & 160 & sl & - & 160 & sl & - \\
\hline 27 & 40 & sl & - & 40 & - & - & 80 & $\mathbf{A g}$ & - & 80 & $\mathrm{Ag}$ & - \\
\hline 28 & 80 & - & - & 40 & - & - & 80 & - & - & 80 & sl & - \\
\hline 29 & 40 & - & - & 40 & 一 & - & 80 & $\mathrm{Ag}$ & sl & 80 & tr & - \\
\hline 30 & 80 & - & - & 80 & - & - & 160 & sl & - & 80 & $\operatorname{tr}$ & - \\
\hline 31 & 160 & - & - & 160 & - & - & 320 & sl & - & 320 & $\mathrm{tr}$ & - \\
\hline 32 & 80 & - & - & 80 & - & - & 80 & $\mathrm{Ag}$ & - & 80 & Ag & - \\
\hline 33 & 40 & 一 & - & 40 & - & - & 80 & sl & - & 40 & $\operatorname{tr}$ & - \\
\hline 34 & 40 & $\mathrm{Ag}$ & sl & 40 & sl & - & 80 & sl & - & 80 & $\mathrm{Ag}$ & $\mathrm{tr}$ \\
\hline 35 & 80 & - & - & 80 & - & - & 80 & $\mathrm{tr}$ & - & 40 & $\mathbf{A g}$ & $\mathrm{tr}$ \\
\hline 36 & 40 & 一 & - & 40 & - & - & 80 & $\mathrm{tr}$ & - & 80 & Ag & - \\
\hline 37 & 40 & sl & - & 20 & - & - & 40 & $\mathrm{tr}$ & - & 40 & $\mathrm{Ag}$ & - \\
\hline 38 & 80 & - & - & 80 & - & - & 160 & $\mathbf{A g}$ & $\mathrm{tr}$ & 80 & $\mathbf{A g}$ & $\mathrm{tr}$ \\
\hline 39 & 80 & - & - & 40 & $\mathbf{A g}$ & sl & 160 & $\mathbf{A g}$ & - & 80 & $\mathrm{Ag}$ & $\mathrm{tr}$ \\
\hline 40 & 80 & - & - & 40 & - & - & 160 & $\mathbf{A g}$ & sl & 160 & $\mathrm{Ag}$ & $\operatorname{tr}$ \\
\hline 41 & 160 & sl & - & 160 & - & - & 160 & $\mathrm{Ag}$ & - & 80 & $\mathbf{A g}$ & - \\
\hline 42 & 40 & - & - & 40 & $\operatorname{tr}$ & - & 40 & sl & - & 40 & $\mathbf{A g}$ & - \\
\hline 43 & 80 & - & - & 80 & - & - & 80 & sl & - & 80 & $\mathbf{A g}$ & - \\
\hline 44 & 40 & $\operatorname{tr}$ & - & 20 & - & - & 20 & $\mathbf{A g}$ & - & 20 & - & - \\
\hline 45 & 80 & - & - & 80 & - & - & 80 & $\mathrm{Ag}$ & - & 80 & sl & - \\
\hline 46 & 80 & - & - & 160 & - & - & 160 & $\mathrm{tr}$ & - & 160 & $\mathrm{tr}$ & - \\
\hline 47 & 80 & $\operatorname{tr}$ & - & 80 & - & - & 80 & sl & - & 80 & Ag & - \\
\hline \multicolumn{13}{|l|}{ Positive } \\
\hline control & 320 & - & - & 640 & - & 一 & 320 & sl & 一 & 320 & Ag & 一 \\
\hline
\end{tabular}

Table II Comparison of rubella HAI and cell agglutinin titres of sera treated with 2 ME and absorbed with strong suspensions of indicator cells

of rubella antigen using methods $\mathrm{A}$ and $\mathrm{B}$. The results are presented in table II. Tests on sera treated with $2 \mathrm{ME}$ and with concentrated cells gave comparable titres. Chick cell agglutinin was removed from 1 in 10 dilutions of serum by either method, but pigeon cell agglutinin often obscured test reading at the 1 in 10 dilution whichever method of serum treatment was used.

COMPARISON OF RUBELLA HAI TITRES OF 26 LOW POSITIVE AND NEGATIVE SERA TREATED WITH CONCENTRATED CHICK CELLS AND 2 ME

Low titred sera were titrated against $6 \mathrm{HA}$ units of rubella antigen using serum treatment with 0.2 molar $2 \mathrm{ME}$ and with $50 \%$ chick cell absorption (method C). The HAI and chick cell agglutinin titres are recorded in table III. HAI titres varied within the limits of experimental error. In some sera heteroagglutinin interfered with the reading of the low titres, and $2 \mathrm{ME}$ was more effective than $50 \%$ chick cells in removing this agglutinin.

When $2 \mathrm{ME}$ was used at the higher concentrations recommended in methods $\mathrm{B}$ and $\mathrm{C}$ there was some distortion of the pattern of specific haemagglutination in serum dilutions up to 1 in 10 . Instead of a shield pattern haemagglutinated cells iormed coarse clumps. There was usually no difficulty in recog- nizing this appearance but at dilutions of 1 in 2.5 and 1 in 5 of a few sera these clumps settled as a loose을 button in the well. This loose button could be distinguished from the compact button of haemag glutination inhibition by reference to the serum. control and by examination with a hand lens. This tendency of haemagglutinated cells to settle at thelow dilutions was also seen in sera absorbed with. concentrated cells.

\section{Discussion}

2 ME disrupts pentameric IgM molecules intog inactive fragments and has been widely used tô remove IgM activity from serum. The results presented in table I and the figure show that hetero 0 agglutinins of chick and pigeon cells in human serat are present mainly in the IgM fractions, and may alsog be inactivated by $2 \mathrm{ME}$. It is possible that even the small amount of agglutinin found in the $\mathrm{IgG}$ con- $\frac{-}{\mathbb{D}}$ taining fractions of sera is IgM which has 'trailed' inf? the gradient, and the absence of IgG peaks in the three specimens tested supports this view.

As well as removing heteroagglutinins $2 \mathrm{ME}_{\mathrm{Q}}^{\mathrm{P}}$ inactivates specific IgM. IgM class antibody does no⿸丆⿰丨丶⿸丆口冂卄 therefore contribute to HAI titres in tests on $2 \mathrm{ME}$ treated sera although it forms, in any case, a negligible proportion of the total specific antibody in sera fromg 


\begin{tabular}{|c|c|c|c|c|c|c|c|c|}
\hline \multirow[t]{3}{*}{ Serum } & \multicolumn{4}{|l|}{$2 M E$ Treated } & \multicolumn{4}{|c|}{ Concentrated Chick Cell Treated } \\
\hline & \multirow{2}{*}{$\begin{array}{l}\text { Reciprocal of } \\
\text { Rubella HAI Titre }\end{array}$} & \multicolumn{3}{|c|}{ Serum Control } & \multirow{2}{*}{$\begin{array}{l}\text { Reciprocal of } \\
\text { Rubella HAI Titre }\end{array}$} & \multicolumn{3}{|c|}{ Serum Control } \\
\hline & & $1 / 2 \cdot 5$ & $1 / 5$ & $1 / 10$ & & $1 / 2 \cdot 5$ & $1 / 5$ & $1 / 10$ \\
\hline 48 & $2 \cdot 5$ & - & - & - & 2.5 & tr & - & - \\
\hline 49 & 10 & - & - & - & 5 & $\mathbf{A g}$ & tr & - \\
\hline 50 & 2.5 & - & - & - & $<10$ & $\mathbf{A g}$ & $\mathbf{A g}$ & tr \\
\hline 51 & 2.5 & tr & - & - & 2.5 & - & - & - \\
\hline 52 & 2.5 & - & - & - & 2.5 & - & - & - \\
\hline 53 & $2 \cdot 5$ & - & - & - & $<10$ & $\mathbf{A g}$ & $\mathbf{A g}$ & tr \\
\hline 54 & 20 & - & - & - & 40 & $\mathbf{A g}$ & sl $\mathbf{A g}$ & - \\
\hline 55 & 2.5 & - & - & - & $2 \cdot 5$ & - & - & - \\
\hline 56 & $2 \cdot 5$ & - & - & - & 2.5 & - & - & - \\
\hline 57 & $2 \cdot 5$ & - & - & - & 2.5 & - & - & - \\
\hline 58 & 20 & - & - & - & 20 & - & - & - \\
\hline 59 & 10 & - & - & - & 20 & $\mathbf{A g}$ & $\mathbf{A g}$ & sl Ag \\
\hline 60 & 2.5 & - & - & - & $2 \cdot 5$ & - & - & - \\
\hline 61 & 20 & - & - & - & 40 & - & - & - \\
\hline 62 & 20 & - & - & - & 20 & - & 一 & - \\
\hline 63 & 2.5 & - & - & - & 2.5 & - & - & - \\
\hline 64 & 40 & - & - & - & 20 & - & - & - \\
\hline 65 & 2.5 & - & - & - & 2.5 & tr & - & - \\
\hline 66 & 2.5 & - & - & - & 2.5 & - & - & - \\
\hline 67 & 2.5 & - & - & - & $2 \cdot 5$ & 一 & - & - \\
\hline 68 & 2.5 & - & - & - & 2.5 & - & - & - \\
\hline 69 & 20 & - & - & - & 20 & - & 一 & - \\
\hline 70 & 2.5 & - & - & - & 2.5 & - & - & - \\
\hline 71 & 10 & - & - & - & 10 & - & 一 & - \\
\hline 72 & 2.5 & - & - & - & 5 & - & - & - \\
\hline 73 & 10 & - & - & - & 10 & - & - & - \\
\hline Negative control & $2 \cdot 5$ & - & - & - & $2 \cdot 5$ & - & - & - \\
\hline Low titre positive control & 10 & - & - & - & 10 & sl & - & - \\
\hline Positive control & 320 & - & - & - & 320 & - & - & - \\
\hline
\end{tabular}

Table III Comparison of rubella HAI titres of low titred sera treated with $2 M E$ and absorbed with a concentrated chick cell suspension

patients with past infection. When acute and convalescent sera are compared specific IgM limits the rise in titre between specimens because it reaches its highest concentrations in the early phase of illness and declines in convalescence. Therefore, neither in tests for immunity nor in the diagnosis of infection by measuring a rising titre is the loss of specific IgM through $2 \mathrm{ME}$ treatment a disadvantage, though sera which are to be fractionated to demonstrate the presence of specific IgM must of course be absorbed with concentrated red cells. The results in table II show that at the concentrations used here $2 \mathrm{ME}$ has no significant effect on IgG antibody.

In testing sera from dilutions as low as 1 in 2.5 inaccuracies may arise both because of loss of antibody absorbed or destroyed by reagents used to prepare the sera, and because of incomplete removal of non-antibody inhibitors. It should be remembered that these factors can be responsible for both false negative and false positive results. While sera that show no inhibition at a dilution of 1 in 2.5 and a clear button of cells in the control wells can only be read as negative, those few sera that show incomplete inhibition at the lowest dilutions should probably be checked by a flotation centrifugation technique to distinguish between the effect of low levels of antibody and residual inhibitor. A method for separating lipoprotein from small samples of serum is referred to by Hatch (1968) and has been used to separate rubella non-specific inhibitors from antibody by Haukenes (1973).

Tests for low titres of rubella HAI antibody have proved useful in resolving puzzling findings in natural and vaccine infections. For instance, an anomalous situation in which a 'seronegative' nurse was immunized twice with rubella vaccine without serological response at a test dilution of 1 in 16 was clarified by titres of 1 in 5,1 in 10, and 1 in 5 being found in sera taken before and after vaccinations. Adult women found to be negative at routine screening dilutions often have low levels of antibody, and if the interpretation of serological findings in natural and vaccine infections is to be correct these low titres must be identified. Their occurrence suggests that a recent primary infection should not be diagnosed by a fourfold rise in titre unless an early serum is negative at a low dilution, or IgM has been detected.

As well as resolving some of the problems that arise in cases and contacts of natural rubella, low titre testing will have an important role in assessing the duration of immunity after rubella vaccination. 
At present $11.8 \%$ of adult women tested at 1 in 16 are seronegative (Hambling, 1975), but $20 \%$ of women negative at 1 in 16 are positive at lower titres (unpublished findings). Serological responses to rubella vaccines are about three times lower than to natural infection (Plotkin and Farquhar, 1972) so this suggests that up to $10 \%$ of children vaccinated at 12 to 13 years of age will have antibody at a titre of less than 1 in 16 in adult life, and that a more sensitive test than is generally used now will be needed in the future.

Although interference by residual non-specific inhibitors in sensitive rubella tests requires further investigation, the use of $2 \mathrm{ME}$ to destroy serum agglutinins enables tests at low dilutions to be carried out without difficulty, as well as simplifying the preparation of sera for routine rubella HAI screening.

I wish to thank Dr M. P. Jevons for providing sera, and Dr M. S. Pereira for help in the preparation of this paper. Since it was written I have learnt that
Dr S. K. R. Clarke, of the Public Health Laboratory, $\stackrel{\stackrel{0}{\overrightarrow{0}}}{\underline{\underline{0}}}$ Bristol, has been using $2 \mathrm{ME}$ to remove agglutinins from kaolin treated sera in routine rubella tests with very satisfactory results.

\section{References}

Biano, S. A., Chang, T. W., and Daniels, J. B. (1974).ळ Rubella hemagglutination inhibition: removal of non- $\vec{P}$ specific agglutination due to manganous chloride. Appl. Microbiol., 28, 992-994.

Hambling, M. H. (1975). Effect of a vaccination programme on the distribution of rubella antibodies in women of childbearing age. Lancet, 1, 1130-1133.

Hatch, F. T. (1968). Practical methods for lipoproteiniv analysis. Advanc. Lipid Res., 6, 1-68.

Haukenes, G. (1973). A rubella hemagglutination inhibitor. simulating antibody. Acta Path. microbiol. scand., B, 81, $\underset{\text { 719-723. }}{\stackrel{\Delta}{\nu}}$

Plotkin, S. A. and Farquhar, J. D. (1972). Immunity to음 rubella: comparison between naturally and artificially induced resistance. Postgrad. med. J., 48, Suppl. 3, 47-54. Z

Saeed, A. A. and Murray, H. G. S. (1975). A nonspecific inhibitor of rubella hemagglutinin in day-old chick cells. Lancet, 2, 413-414. 